ISSN 2073-4441

www.mdpi.com/journal/water

Article

\title{
Impact of Rural Domestic Wastewater Irrigation on the Physicochemical and Microbiological Properties of Pakchoi and Soil
}

\author{
Bo Yang ${ }^{1, \dagger}$, Xiao Kong ${ }^{1,2, \dagger}$, Bingjian Cui ${ }^{2,3, \dagger}$, Decai Jin ${ }^{2,3, \dagger}$, Ye Deng ${ }^{2,3}$, Xuliang Zhuang ${ }^{2,3}$, \\ Guoqiang Zhuang ${ }^{2,3}$ and Zhihui Bai ${ }^{2,3, *}$
}

1 College of Environment and Safety Engineering, Qingdao University of Science and Technology, Qingdao 266042, China; E-Mails: yangbo16@126.com (B.Y.); kongxiaozaikeda@163.com (X.K.)

2 Key Laboratory of Environmental Biotechnology, Research Center for Eco-Environmental Sciences, Chinese Academy of Sciences, Beijing 100085, China;

E-Mails: cuibingjian12b@mails.ucas.ac.cn (B.C.); jindecai19841019@gmail.com (D.J.); yedeng@rcees.ac.cn (Y.D.); xlzhuang@rcees.ac.cn (X.Z.); gqzhuang@rcees.ac.cn (G.Z.)

3 College of Resources and Environment, University of Chinese Academy of Sciences, Beijing 100049, China

$\dagger$ These authors contributed equally to this work.

* Author to whom correspondence should be addressed; E-Mail: zhbai@rcees.ac.cn; Tel.: +86-10-6284-9156; Fax: +86-10-6292-3563.

Academic Editor: Miklas Scholz

Received: 27 January 2015 / Accepted: 15 April 2015 / Published: 27 April 2015

\begin{abstract}
Great attention has been paid to the potential of wastewater irrigation as a sustainable water source, particularly due to water scarcity and water pollution issues. However, few studies have focused on its adverse effects and on the health risks it may pose. In this study, the physicochemical properties of soils and plants irrigated with rural domestic wastewater and associated microbiological risks were investigated. The results showed that sewage irrigation could increase the production of vegetables and improve soil fertility. While the nitrate content of plants increased significantly, pathogens on plants and in soils increased after irrigation with raw wastewater. In particular, there was a wide range of pathogenic bacteria in the phyllosphere, which may indicate risks if contaminated vegetables are consumed directly. Treated wastewater irrigation was not significantly different from controls, which were irrigated by tap water; consequently, it can be used as an
\end{abstract}


alternative water resource for agricultural irrigation. The presence of a wide spectrum pathogens in wastewater shows the necessity of long-term monitoring and further evaluation.

Keywords: rural domestic wastewater; pathogens; pakchoi; real-time quantitative PCR; phyllosphere

\section{Introduction}

The geographic distribution of water resources in China is very non-uniform, with $90 \%$ of surface water and $70 \%$ of groundwater distributed in various southern provinces. North China, which is situated in an arid and semi-arid climatic belt, receives less rainfall and experiences higher evaporation; it has consequently become one of the main water-deficient areas, particularly as the local demand for water has increased so rapidly with economic development and population growth, that it already surpasses local water supply capacity. Moreover, growing water pollution renders the situation even more serious. Water shortages and poor water quality are interacting with each other and seriously constraining economic and social development [1-3].

The scarcity of water resources has increasingly rendered recycled wastewater a valid substitute resource [4]. Treated wastewater is used directly for irrigation in many countries, especially in arid and semiarid areas. It contains essential plant nutrients, such as $\mathrm{Ca}, \mathrm{Mg}, \mathrm{K}, \mathrm{N}, \mathrm{P}$ and $\mathrm{Fe}$, that are important for plant growth [5]. The reuse of treated wastewater avoids this being discharged into sensitive environments [6,7], helps conserve water resources, recycles nutrients $(\mathrm{N}$ and $\mathrm{P})$ and minimizes pollution loads in receiving water bodies [8]. However, wastewater also contains various inorganic substances, including potential toxic elements and heavy metals $(\mathrm{Cr}, \mathrm{Cd}, \mathrm{Pb}, \mathrm{Ni}$ and $\mathrm{Hg}$ ) [9], which may be at phytotoxic levels or create health risks [10,11]. Safe and efficient management of this resource therefore cannot be achieved without appropriate monitoring [12], given that wastewater reuse also involves many potential risks to soil quality and to the growth and quality of crops [13-15].

Considerable research has been focused on the effect of wastewater irrigation on soil properties and on the quality of vegetables. Lado et al. [6] studied the effect of long-term secondary treated wastewater irrigation on soil chemical properties. Lv et al. [16] reported the effect of sewage irrigation on growth and development, yield and quality of potato. Similarly, Fayyad et al. [17] conducted a field experiment to investigate the effect of different treatments of potable and treated wastewater on the quality of tomato fruit. Singh et al. [18] described a year-long experiment to observe the effect of sewage wastewater irrigation on soil properties, crop yield and the environment. Maldonado et al. [19] conducted research on heavy metal content in soils under different wastewater irrigation patterns. However, little attention has been concentrated on the microbiological risk of wastewater irrigation.

The consumption of contaminated vegetables presents a potential risk to human health, with these containing large numbers of microbial pathogens in addition to heavy metals and other potential toxic elements. The presence of pathogenic bacteria may pose a health hazard for consumers of raw fruits and vegetables [20]. For example, Arcobacter spp. can cause persistent diarrhea, accompanied by abdominal pain, stomach cramps, nausea, vomiting, fever and other symptoms, and the infection rate is difficult to assess. 
Given the significance of these risks, in this study, we tested the content of pathogenic microorganisms in rural domestic sewage and conducted research on pathogen residues on the surfaces of leaves and in soil of plant roots using real-time quantitative PCR. Additionally, the effects of wastewater irrigation on growth and nutrition plant indices were also investigated.

\section{Experimental Section}

\subsection{Experimental Design}

The experiment was performed in a greenhouse at Beijing Forestry University Forestry Science Co. Ltd. (4000'96" N, 116 $34^{\prime} 69^{\prime \prime} \mathrm{E}$, Beijing, China). The original experimental soil was collected from suburban farmland of Beijing. Table 1 lists the physicochemical characteristics of this soil.

Table 1. Physicochemical properties of the experimental soil sample.

\begin{tabular}{|c|c|c|c|}
\hline Parameters & \multicolumn{3}{|c|}{ Soil } \\
\hline \multirow{5}{*}{ Soil particle proportion $(\%)$} & $>0.05 \mathrm{~mm}$ & 31.25 & \multirow{2}{*}{ sand } \\
\hline & $0.05-0.02 \mathrm{~mm}$ & 22.20 & \\
\hline & $0.02-0.005 \mathrm{~mm}$ & 13.40 & \\
\hline & $0.005-0.002 \mathrm{~mm}$ & 6.30 & lime \\
\hline & $<0.002 \mathrm{~mm}$ & 26.85 & clay \\
\hline $\mathrm{pH}$ & \multicolumn{3}{|c|}{7.96} \\
\hline $\mathrm{EC}(\mu \mathrm{s} / \mathrm{cm})$ & \multicolumn{3}{|c|}{571} \\
\hline Organic matter $(\mathrm{g} / \mathrm{kg})$ & \multicolumn{3}{|c|}{1.58} \\
\hline $\mathrm{NO}_{3}-\mathrm{N}(\mathrm{mg} / \mathrm{kg})$ & \multicolumn{3}{|c|}{8.56} \\
\hline $\mathrm{NH}_{3}-\mathrm{N}(\mathrm{mg} / \mathrm{kg})$ & \multicolumn{3}{|c|}{0.063} \\
\hline Available P (mg/kg) & \multicolumn{3}{|c|}{3.1} \\
\hline Available K (mg/kg) & \multicolumn{3}{|c|}{107.7} \\
\hline $\mathrm{Cu}(\mathrm{mg} / \mathrm{kg})$ & \multicolumn{3}{|c|}{20.3} \\
\hline $\mathrm{Zn}(\mathrm{mg} / \mathrm{kg})$ & \multicolumn{3}{|c|}{67.3} \\
\hline $\mathrm{Cd}(\mathrm{mg} / \mathrm{kg})$ & \multicolumn{3}{|c|}{0.023} \\
\hline $\mathrm{Pb}(\mathrm{mg} / \mathrm{kg})$ & \multicolumn{3}{|c|}{36.3} \\
\hline
\end{tabular}

Wastewaters were obtained from a rural domestic wastewater treatment plant, with a membrane bioreactor (MBR) processes (Figure 1), located in Huairou District of Beijing; the water samples' quality parameters are shown in Table 2.

Pakchoi seeds were purchased from the Chinese Academy of Agricultural Sciences (CAAS). The seeds were surface sterilized using 3\% sodium hypochlorite solution disinfection for 15 min, followed by several cycles of rinsing with sterilized distilled water. The sterile seeds were then placed in a petri dish to sprout at room temperature and appropriate humidity. 


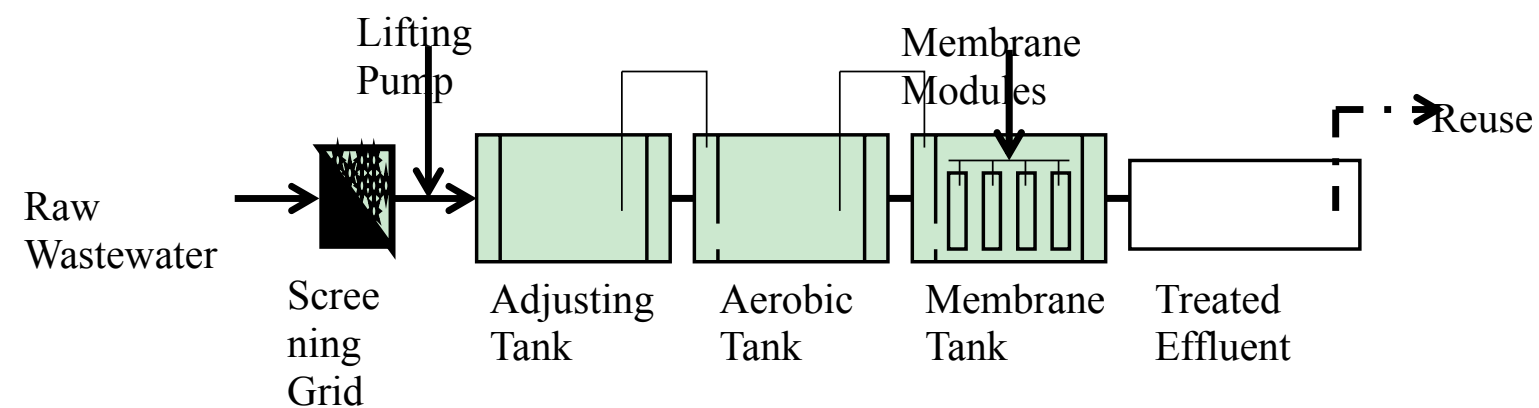

Figure 1. Process flow diagram of the wastewater treatment system with a membrane bioreactor.

Table 2. Physical and chemical properties of experimental water samples.

\begin{tabular}{|c|c|c|c|c|}
\hline Parameters & Raw Wastewater & Treated Wastewater & $\begin{array}{c}\text { Criteria of Tap } \\
\text { Water [21] }\end{array}$ & $\begin{array}{c}\text { Criteria of Irrigation } \\
\text { Water [22] }\end{array}$ \\
\hline $\mathrm{pH}$ & 7.60 & 7.59 & $6.5-8.5$ & $5.5-8.5$ \\
\hline $\mathrm{EC}(\mu \mathrm{s} / \mathrm{cm})$ & 754 & 376 & -- & $\leq 1,000$ \\
\hline Salinity (mg/L) & $415-566$ & $207-282$ & $\leq 1,000$ (TDS) & - \\
\hline Temperature $\left({ }^{\circ} \mathrm{C}\right)$ & 12.2 & 12.1 & -- & $\leq 35$ \\
\hline $\mathrm{COD}(\mathrm{mg} / \mathrm{L})$ & 346 & 35 & -- & $\leq 100^{\mathrm{a}}$ or $60^{\mathrm{b}}$ \\
\hline $\mathrm{SS}(\mathrm{mg} / \mathrm{L})$ & 26 & 21 & -- & $\leq 60^{\mathrm{a}}$ or $15^{\mathrm{b}}$ \\
\hline anionic surfactant $(\mathrm{mg} / \mathrm{L})$ & 2.00 & no detectable $(<0.05)$ & $\leq 0.3$ & $\leq 5$ \\
\hline $\mathrm{TN}(\mathrm{mg} / \mathrm{L})$ & 54.6 & 26.2 & -- & -- \\
\hline $\mathrm{TP}(\mathrm{mg} / \mathrm{L})$ & 4.97 & 7.66 & -- & -- \\
\hline $\mathrm{Zn}(\mathrm{mg} / \mathrm{L})$ & 0.153 & no detectable $(<0.006)$ & $\leq 1.0$ & $\leq 2$ \\
\hline $\mathrm{Cu}(\mathrm{mg} / \mathrm{L})$ & no detectable $(<0.01)$ & no detectable $(<0.01)$ & $\leq 1.0$ & $\leq 1$ \\
\hline $\mathrm{Pb}(\mathrm{mg} / \mathrm{L})$ & 0.003 & no detectable $(<0.001)$ & $\leq 0.01$ & $\leq 0.2$ \\
\hline $\mathrm{Cd}(\mathrm{mg} / \mathrm{L})$ & 0.0002 & 0.0002 & $\leq 0.005$ & $\leq 0.01$ \\
\hline $\mathrm{Cl}^{-}(\mathrm{mg} / \mathrm{L})$ & 44.2 & 56.1 & $\leq 250$ & $\leq 350$ \\
\hline $\mathrm{NH}_{3}-\mathrm{N}(\mathrm{mg} / \mathrm{L})$ & 45.7 & 8.59 & $\leq 0.5$ & -- \\
\hline $\mathrm{NO}_{3}-\mathrm{N}(\mathrm{mg} / \mathrm{L})$ & no detectable $(<0.2)$ & 16.0 & $\leq 20$ & -- \\
\hline Total bacteria count $/ \mathrm{mL}$ & $(1.24 \pm 0.05) \times 10^{6}$ & $(2.80 \pm 0.20) \times 10^{5}$ & $\leq 100$ & -- \\
\hline Total coliforms $/ \mathrm{mL}$ & $6.05 \times 10^{5} \pm 1.75 \times 10^{5}$ & no detectable $(<30)$ & no detectable & -- \\
\hline Fecal coliforms $/ \mathrm{mL}$ & 240,000 & no detectable $(<3)$ & no detectable & $\leq 20^{\mathrm{a}}$ or $10^{\mathrm{b}}$ \\
\hline Escherichia coli & $8.9 \times 10^{4}$ & no detectable $(<30)$ & no detectable & -- \\
\hline $\begin{array}{c}\text { Ascaris Lumbricoides } \\
(\mathrm{eggs} / \mathrm{L})\end{array}$ & 34 & no detectable & no detectable & $\leq 2^{\mathrm{a}}$ or $1^{\mathrm{b}}$ \\
\hline
\end{tabular}

Notes: ${ }^{a}$ Vegetables need processing, cooking or peeling; ${ }^{\mathrm{b}}$ rabbit food, melons and fruit; --, no data; TDS, total dissolved solids.

The soil was air-dried and sieved (20 mesh). Each pot $(23 \mathrm{~cm}$ in top diameter, $16 \mathrm{~cm}$ bottom and $20 \mathrm{~cm}$ high) contained $2.5 \mathrm{~kg}$ dry soil and 20 seeds of pakchoi. After germination, the seedlings were thinned out, and 10 seedlings were left for growth. Irrigation was carried out from the seedling stage based on actual water requirement (irrigated approximately every 3 days, $100 \mathrm{~mL}$ at a time in one pot, 12 times and $1200 \mathrm{~mL}$ in total), with a specified amount of conventional fertilizer $(0.15 \mathrm{~g}$ urea, $0.06 \mathrm{~g}$ calcium superphosphate, $0.15 \mathrm{~g}$ potassium sulfate per pot) added to the water. After the plants matured (about 6 weeks), the vegetables were harvested in summer 2013. Then, the second round of planting 
was performed with the same method in autumn 2013. The third round of the experiments began on 19 March 2014 and extended until 5 May 2014 with the same method for the long-term investigation of the effect of wastewater irrigation.

Experimental treatments involved surface irrigation with three types of water: tap-water (DW), raw wastewater (WW) and treated wastewater (TW). At the same time, controls with nothing sowed and irrigated with tap water (CK-DW) and raw wastewater (CK-WW) were set up. Each treatment was applied in four replicates with a randomized block design.

\subsection{Collection of Microbial Samples and DNA Extraction}

After the third round of planting, vegetables were harvested at maturity (about 6 weeks) using sterile scissors, which separated the aboveground parts and roots. Harvested plants were placed in valve bags and transported immediately to the laboratory for analysis.

Leaves (10 g) were stuffed in an aseptic polypropylene tube containing $100 \mathrm{~mL}$ sodium phosphate buffer $(0.2 \mathrm{M}, \mathrm{pH} 7.0)$, shaken for $30 \mathrm{~min}$ in a vapor-bathing constant temperature vibrator and then treated by ultrasonic waves $(40 \mathrm{kHz}$ ) for $30 \mathrm{~min}$ using ultrasonic agitation (Ningbo Xingzhi Biological Technology Co. Ltd., Ningbo, China). The buffer solution was then filtered through a $0.22-\mu \mathrm{M}$ cellulose nitrate microporous composite membrane. The microbes from the leaves were accumulated on the membrane, which was stored at $-80^{\circ} \mathrm{C}$ subsequently.

Surface soil and rhizosphere soil samples of each pot were air-dried in a sterile chamber at room temperature, then sieved through a 20 mesh sieve and stored at $-80{ }^{\circ} \mathrm{C}$.

Water samples were filtered through $0.22-\mu \mathrm{m}$ membranes to collect microbes, then the membrane was put in a sterile centrifuge tube and stored at $-80{ }^{\circ} \mathrm{C}$.

Genomic DNA of the above microbes' samples was extracted using the Fast DNA SPIN Kit for Soil (MP Biomedicals, Santa Ana, CA, USA) following the manufacturer's instructions.

\subsection{Physical and Chemical Properties Detection of Plants and Soil}

The $\mathrm{pH}$ and electrical conductivity (EC) of soil samples were detected in aqueous extract (soil:deionized water $=1: 5$ ) using a multi-parameter water quality monitoring instrument [23]. Organic matter was measured using the potassium bichromate titrimetric method. The activity of urease and phosphatase was assayed based on the method of Tabatabai [24].

Fresh and dry weights of mature plants were measured by the gravimetric method, and the plants' height was measured by a ruler. The salicylic acid method was used to measure the vegetables' nitrate content [25], while soluble sugar was determined by the anthrone colorimetry method [26]. The Coomassie Brilliant Blue G250 staining method was used to determine the concentration of soluble protein in vegetable samples [27]. The vegetables' vitamin C content was determined by the 2,6-diohloroindophenol titration method [28]. 


\subsection{Molecular Assays}

This study focused on common pathogens, including pathogens present in the environment and several pathogens that have emerged as a focus of research interest in recent years. Specific pathogens considered were: Aeromonas hydrophila, Arcobacter spp., Bacillus cereus, Clostridium difficile, Clostridium perfringens, Escherichia coli, Legionella spp. and Mycobacterium spp.

Traditional PCR was conducted to confirm the presence of pathogens. Based on the PCR results, positive pathogens were investigated further, with the corresponding primer pairs for each target and expected product size shown in Table 3.

Table 3. Primers of pathogenic bacteria for real-time PCR assays.

\begin{tabular}{ccccc}
\hline $\begin{array}{c}\text { Pathogenic } \\
\text { Bacteria }\end{array}$ & $\begin{array}{c}\text { Targeted } \\
\text { Gene }\end{array}$ & Primer Sequences & $\begin{array}{c}\text { Amplicon } \\
\text { Size (bp) }\end{array}$ & Ref. \\
\hline $\begin{array}{c}\text { Aeromonas } \\
\text { hydrophila }\end{array}$ & $\begin{array}{c}\text { Cytolytic } \\
\text { enterotoxin }\end{array}$ & $\begin{array}{c}\text { AHCF1: GAGAAGGTGACCACCAAGAACA } \\
\text { AHCR1: AACTGACATCGGCCTTGAACTC }\end{array}$ & 232 & {$[29]$} \\
\hline Arcobacter spp. & $23 \mathrm{~S}$ rRNA & $\begin{array}{c}\text { ARCO1: GTCGTGCCAAGAAAAGCCA } \\
\text { ARCO2: TTCGCTTGCGCTGACAT }\end{array}$ & 331 & {$[30]$} \\
\hline Bacillus cereus & $16 \mathrm{~S}$ rRNA & $\begin{array}{c}\text { F: TCGAAATTGAAAGGCGGC } \\
\text { R: GGTGCCAGCTTATTCAAC }\end{array}$ & 288 & {$[31]$} \\
\hline Clostridium difficile & $16 \mathrm{~S}$ rRNA & $\begin{array}{c}\text { Clo-16F: TTGAGCGATTTACTTCGGTAAAGA } \\
\text { Clo-16R: CCATCCTGTACTGGCTCACCT }\end{array}$ & 157 & {$[32]$} \\
\hline $\begin{array}{c}\text { Clostridium } \\
\text { perfringens }\end{array}$ & $16 \mathrm{~S}$ rRNA & $\begin{array}{c}\text { Clp-F: ATGCAAGTCGAGCGA(G/T)G } \\
\text { Clp-R: TATGCGGTATTAATCT(C/T)CCTTT }\end{array}$ & 120 & {$[32]$} \\
\hline Escherichia coli & uidA & $\begin{array}{c}\text { Eco-F: CTGCTGCTGTCGGCTTTA } \\
\text { Eco-R: CCTTGCGGACGGGTAT }\end{array}$ & 205 & {$[33]$} \\
\hline Legionella spp. & $16 \mathrm{~S}$ rRNA & $\begin{array}{c}\text { LEG448:GAGGGTTGATAGGTTAAGAGC } \\
\text { LEG858:GTCAACTTATCGCGTTTGCT }\end{array}$ & 430 & {$[34]$} \\
\hline Mycobacterium spp. & $16 \mathrm{~S}$ rRNA & $\begin{array}{c}\text { Myco F: ATGCACCACCTGCACACAGG } \\
\text { Myco R: GGTGGTTTGTCGCGTTGTTC }\end{array}$ & 470 & {$[35]$} \\
\hline
\end{tabular}

Positive PCR products were purified with the E.Z.N.A. ${ }^{\text {TM }}$ Gel Extraction Kit (Omega Bio-tek, Norcross, GA, USA) and ligated to a pGEM-T Easy vector system I (Promega, Madison, WI, USA). Recombinant plasmids were transferred into E. coli DH5a-competent cells (Biomed, Beijing, China) and coated on LB agar plates containing ampicillin, X-gal and IPTG, as recommended by the manufacturer. PCR was performed to confirm the sizes of insert fragments and sequenced by Ruibio BioTech Co., Ltd. (Beijing, China). The gene sequences were aligned by BLAST [36] on NCBI. Plasmid DNA was extracted using the E.Z.N.A. ${ }^{\text {TM }}$ Plasmid Mini Kit I (Omega Bio-tek, Norcross, GA, USA). The gene copy number was calculated according to concentrations of plasmid DNA determined by a Nanodrop2000 UV-VIS Spectrophotometer (Thermo Scientific, Waltham, MA, USA) [37]. The plasmid was diluted using the ten-fold dilution method and used as the standard curve for the quantitative PCR.

Real-time PCR amplification was performed in a $20-\mu \mathrm{L}$ reaction volume using GoTaq qPCR Master Mix (Promega, Madison, WI, USA) on a Stratagene Mx3005P instrument (Agilent Technology, Santa Clara, CA, USA). The PCR mixture contained $10 \mu \mathrm{L}$ of Master Mix, $0.5 \mu \mathrm{L}$ of each primer 
$\left(10 \mu \mathrm{M} \cdot \mathrm{L}^{-1}\right), 2 \mu \mathrm{L}$ of template DNA and $7 \mu \mathrm{L}$ nuclease-free water. The reaction procedure was as follows: $95{ }^{\circ} \mathrm{C}$ for $2 \mathrm{~min}, 45$ cycles at $95{ }^{\circ} \mathrm{C}$ for $15 \mathrm{~s}, 58-62{ }^{\circ} \mathrm{C}$ for $45 \mathrm{~s}, 72{ }^{\circ} \mathrm{C}$ for $45 \mathrm{~s}$. All experiments were performed in triplicate. For each run, template DNA was replaced with double-distilled water as a negative control.

\subsection{Statistical Analysis}

Statistical analyses were performed with Microsoft Office Excel 2013 and SPSS Statistics 19.0. In all cases, differences were considered to be significant if the $p$-value for the $\chi^{2}$ test was less than 0.05 .

\section{Results and Discussion}

\subsection{Effects of Sewage Irrigation on Soil Properties}

In order to investigate the influence of rural domestic wastewater on the soil and plant properties, we compared the basic soil chemical properties after irrigating with tap and wastewater for three seasons. The results showed that the soil $\mathrm{pH}$ decreased after planting and irrigation, mainly because of the neutralization. There was no significant difference in soil $\mathrm{pH}$ between non-planted soils irrigated with tap water and wastewater, while soil $\mathrm{pH}$ was significantly higher in non-planted than in planted soil (Figure 2), because the $\mathrm{pH}$ of plant root exudates is lower than soil. On the other hand, it can be seen from Figure 1 that soil $\mathrm{pH}$ declined significantly after planting and irrigation, regardless of whether this took place with wastewater or tap water. The result indicated that wastewater irrigation may not significantly affect soil $\mathrm{pH}$, but that vegetables may indicate the significant influence of this parameter. The $\mathrm{pH}$ of all of the soil samples meets the standards for farmland soil [38].

Electrical conductivity(EC) and salinity (positively correlated with each other) of soil irrigated with wastewater were significantly lower than in soil irrigated with tap water and treated wastewater, due to the wastewater irrigated plants growth being better, so that more mineral salts were absorbed by the plant. EC and salinity of soil increased regardless of the source of irrigation water, due to the mineral salts from irrigation water being concentrated in soil with water evaporation. Soil salinities of all soil samples are lower than the standard limit $(1.0 \mathrm{~g} / \mathrm{kg})$ of the environmental quality evaluation standards for farmland for edible agricultural products [38].

The difference in organic matter $(\mathrm{OM})$ among different treatments is not significant $(p>0.05)$. However, we can see from Figure 1 that $\mathrm{OM}$ increased after the irrigation. This might be because the irrigation promoted lichen and autotrophic bacteria growth. Soil organic matter contains a large number of major elements and trace elements that are essential for plant growth, and it is therefore one of the important indicators of soil fertility [39]. On the other hand, growth-promoting substances, such as vitamins, amino acids, plant hormone and gibberellin, are released when soil organic matter degrades, stimulating the growth of higher plants and microorganisms [40].

The urease activities of soil irrigated with wastewater have no significant difference with the control and those of soil irrigated with treated water. This activity increased in all treatments after the experiment, possibly because $\mathrm{N}$ and $\mathrm{P}$ fertilizers were added during the course of the experiment. The phosphatase activity of soil irrigated by wastewater was not significantly different than that of soil irrigated with tap water or treated wastewater. However, values were lower in planted treatments than 
in unplanted ones. The results indicate that changes in $\mathrm{N}$ and $\mathrm{P}$ fertilizers led to an increase of phosphatase activity, and $\mathrm{P}$ was greatly in demand by the plant. The conversion speed of organic and inorganic nutrients in soil mainly depends on the enzymatic reaction of redox enzymes. Soil enzyme activity could reflect the strength and direction of biochemical processes and is an important index for evaluating soil fertility and self-purification ability. It is therefore important to improve soil enzyme activity in order to improve the soil ecological environment and soil fertility.
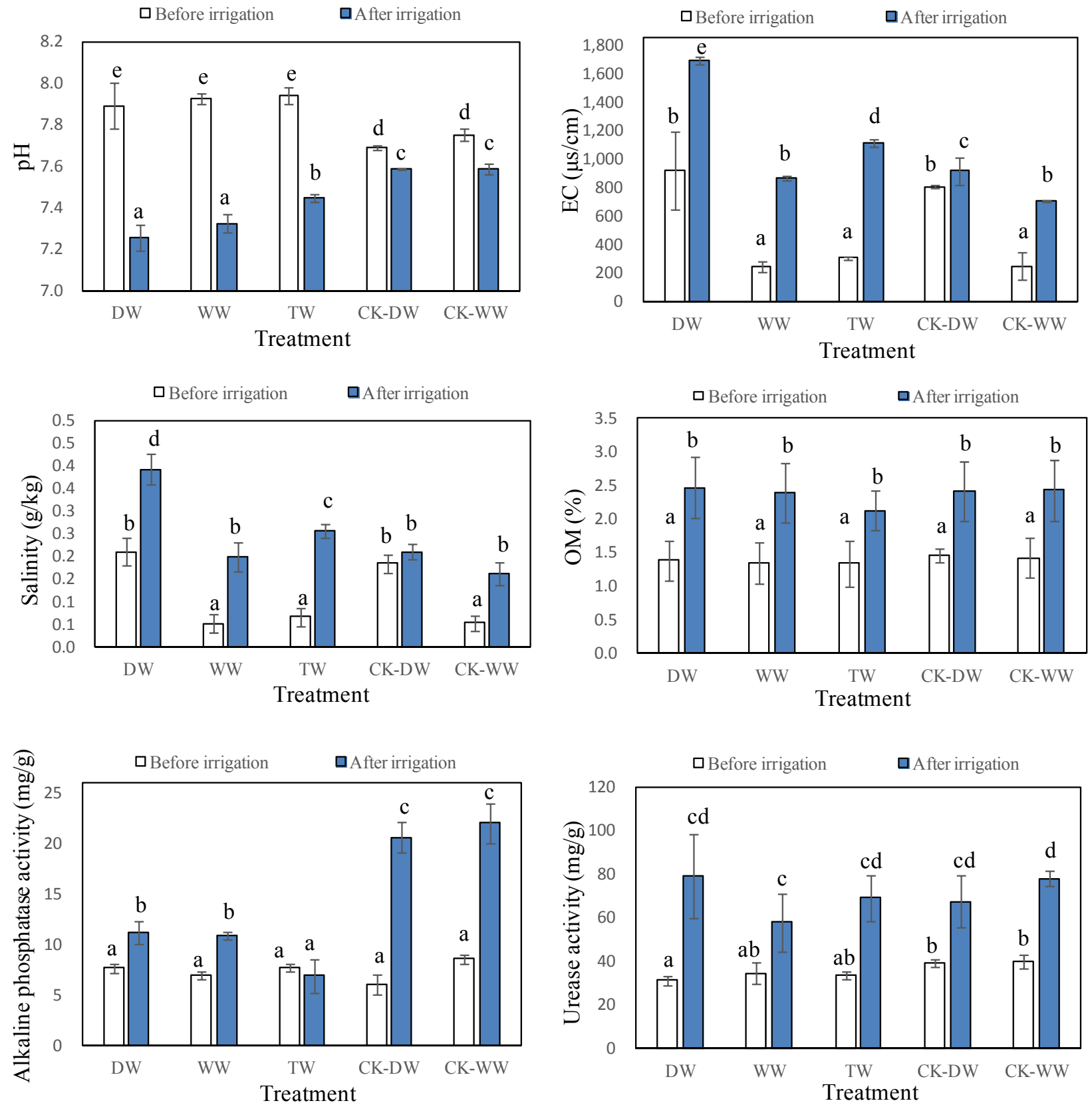

Figure 2. Properties of soil before and after irrigation of the third season planting. Abbreviations: DW, treatment irrigated with tap water and plant; WW, treatment irrigated with wastewater and plant; TW, treatment irrigated with treated wastewater and plant; CK-DW, treatment with no plant and irrigated with tap water; CK-WW, treatment with no plant and irrigated with wastewater. The standard deviation of the mean $(n=3)$ is shown; different letters demonstrate a significant difference at $p<0.05$ based on ANOVA test analysis. 


\subsection{Effects of Sewage Irrigation on Plant Properties}

Table 4 shows the quality parameters of pakchoi after the experiment. The height and fresh weight of vegetables irrigated with wastewater were significantly higher than those of vegetables irrigated with tap water and slightly higher than those of vegetables irrigated with treated wastewater. The height and fresh weight of vegetables irrigated with treated wastewater were higher than those of vegetables irrigated with tap water, but the difference was not significant $(p>0.05)$. The result indicates that wastewater irrigation could greatly increase the output of pakchoi and that irrigation with treated wastewater led to a slight increase in output.

Table 4. Quality parameters of pakchoi following irrigation with DW (control), WW and TW.

\begin{tabular}{ccccccc}
\hline Samples & $\begin{array}{c}\text { Height } \\
(\mathbf{c m})\end{array}$ & $\begin{array}{c}\text { Fresh } \\
\text { Weight }(\mathbf{g})\end{array}$ & $\begin{array}{c}\text { Soluble Sugar } \\
\mathbf{( \% )}\end{array}$ & $\begin{array}{c}\text { Soluble Protein } \\
(\mathbf{m g} / \mathbf{g})\end{array}$ & $\begin{array}{c}\text { Nitrate } \\
(\mathbf{g} / \mathbf{k g})\end{array}$ & $\begin{array}{c}\text { Vc } \\
(\mathbf{m g} / \mathbf{g})\end{array}$ \\
\hline DW & $15.25 \pm 0.76^{\mathrm{a}}$ & $5.06 \pm 0.57^{\mathrm{a}}$ & $0.18 \pm 0.04^{\mathrm{a}}$ & $9.74 \pm 0.33^{\mathrm{a}}$ & $1.19 \pm 0.10^{\mathrm{a}}$ & $1.02 \pm 0.11^{\mathrm{a}}$ \\
WW & $19.18 \pm 0.76^{\mathrm{b}}$ & $10.83 \pm 1.22^{\mathrm{c}}$ & $0.16 \pm 0.01^{\mathrm{a}}$ & $10.16 \pm 0.42^{\mathrm{a}}$ & $1.53 \pm 0.09^{\mathrm{a}, \mathrm{b}}$ & $1.06 \pm 0.19^{\mathrm{a}}$ \\
TW & $17.75 \pm 0.89^{\mathrm{a}, \mathrm{b}}$ & $7.31 \pm 1.05^{\mathrm{a}, \mathrm{b}}$ & $0.15 \pm 0.01^{\mathrm{a}}$ & $9.26 \pm 0.11^{\mathrm{a}}$ & $1.58 \pm 0.07^{\mathrm{b}}$ & $0.89 \pm 0.08^{\mathrm{a}}$ \\
\hline
\end{tabular}

Notes: The standard deviation of the mean $(n=3)$ is shown; ${ }^{a, b, c}$ different letters demonstrate a significant difference at $p<0.05$ based on ANOVA test analysis.

Wastewater irrigation did not make significant changes in the content of soluble sugar, soluble protein and vitamin $\mathrm{C}(\mathrm{Vc})$, which means that wastewater irrigation had no clear influence on the nutritional quality of pakchoi. However, nitrate content significantly increased after irrigation with wastewater. Human consumption of vegetables in which nitrates exceed relevant standards may be seriously harmful to health; for this reason, even if the nitrate content of vegetables irrigated with wastewater conformed to safety standards (agricultural product-safety requirements for non-environmental pollution vegetables: GB18406.1-2001), further studies should be carried out on this aspect.

\subsection{Quantitative PCR Detection of Pathogenic Bacteria}

Real-time PCR detection of pathogenic microorganisms was conducted to monitor the amount of pathogens in wastewater, plant phyllosphere, rhizosphere and non-rhizosphere soil. The number of pathogenic bacteria in each sample is shown in Table 5 and Figure 3.

Table 5. Number of pathogens in wastewater and treated wastewater.

\begin{tabular}{|c|c|c|}
\hline Pathogens & WW (Copies/L) ${ }^{a}$ & TW (Copies/L) ${ }^{\text {b }}$ \\
\hline Aeromonas hydrophila & $(5.48 \pm 0.22) \times 10^{10}$ & $(1.96 \pm 0.02) \times 10^{7}$ \\
\hline Arcobacter spp. & $(1.01 \pm 0.04) \times 10^{11}$ & $(1.45 \pm 0.01) \times 10^{8}$ \\
\hline Bacillus cereus & $(2.01 \pm 0.10) \times 10^{8}$ & $(2.02 \pm 0.06) \times 10^{7}$ \\
\hline Clostridium difficile & $(4.20 \pm 0.10) \times 10^{6}$ & $(6.35 \pm 0.11) \times 10^{4}$ \\
\hline Clostridium perfringens & $(2.85 \pm 0.09) \times 10^{9}$ & $(5.00 \pm 0.25) \times 10^{4}$ \\
\hline E. coli & $(1.02 \pm 0.06) \times 10^{9}$ & $(2.40 \pm 0.36) \times 10^{5}$ \\
\hline Legionella spp. & $(1.27 \pm 0.09) \times 10^{6}$ & $(6.10 \pm 0.77) \times 10^{5}$ \\
\hline Mycobacterium spp. & $(5.71 \pm 0.40) \times 10^{7}$ & $(3.17 \pm 0.35) \times 10^{7}$ \\
\hline Total bacteria & $(3.13 \pm 0.38) \times 10^{11}$ & $(1.56 \pm 0.08) \times 10^{10}$ \\
\hline
\end{tabular}

Notes: The standard deviation of the mean $(n=3)$ is shown; different letters $\left({ }^{a}, b\right)$ demonstrate a significant difference at $p<0.05$ based on ANOVA test analysis. 

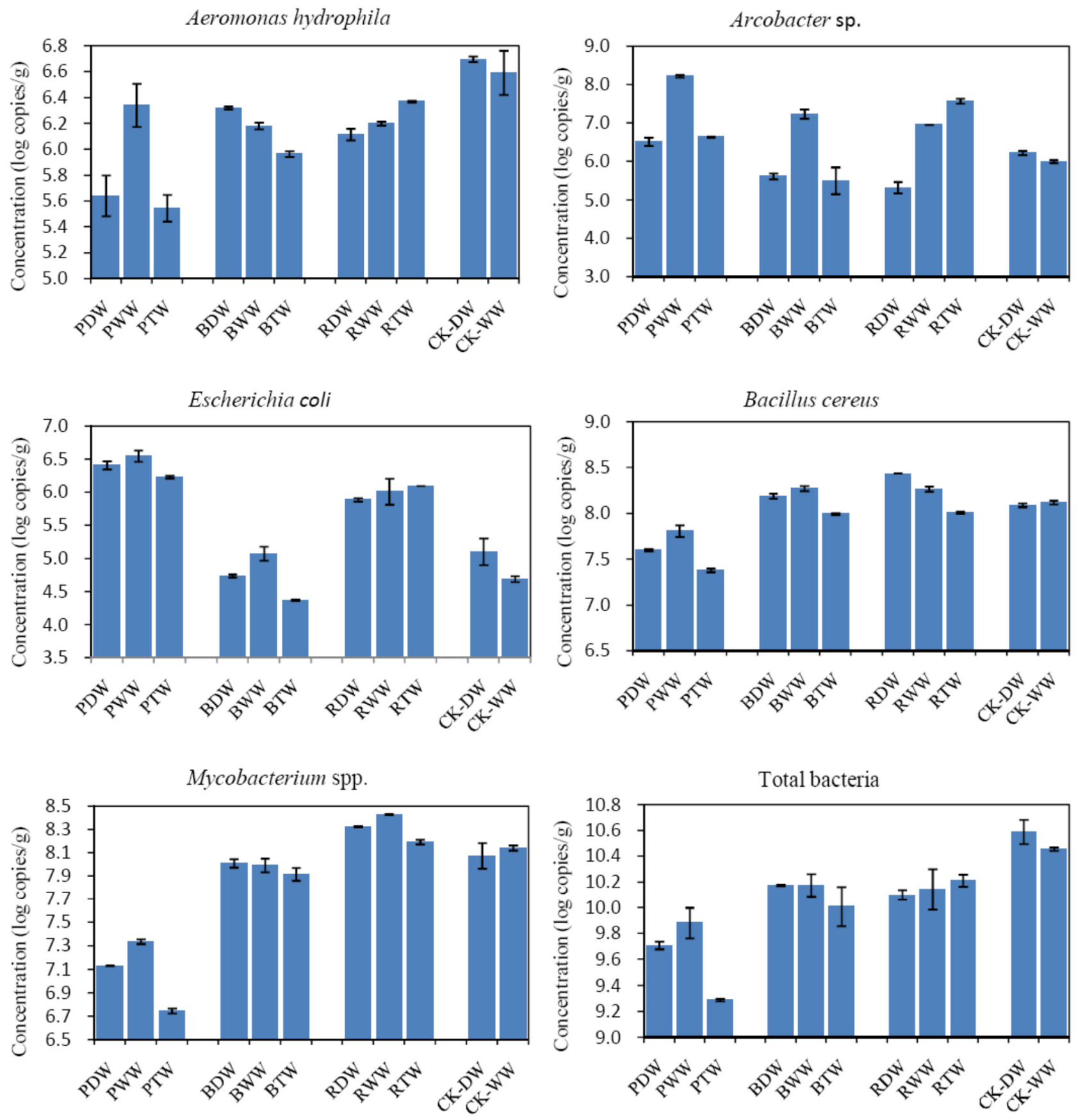

Figure 3. Pathogenic bacteria in each sample. Abbreviations: PDW, phyllosphere irrigated with tap water; PWW, phyllosphere irrigated with wastewater; PTW, phyllosphere irrigated with treated wastewater; BDW, non-rhizosphere irrigated with tap water; BWW, non-rhizosphere irrigated with wastewater; BTW, non-rhizosphere irrigated with treated wastewater; RDW, rhizosphere irrigated with tap water; RWW, rhizosphere irrigated with wastewater; RTW, rhizosphere irrigated with treated wastewater.

In raw wastewater and treated wastewater, Aeromonas hydrophila, Arcobacter spp., Bacillus cereus, Clostridium difficile, Clostridium perfringens, E. coli, Legionella spp. and Mycobacterium spp. were detected. Of these, Clostridium difficile, Clostridium perfringens and Legionella spp. were not found in other samples. Most of the pathogens decreased after treatment. The result shows that although the 
sewage treatment could remove pathogenic microorganisms significantly, treated wastewater would still contain numerous pathogens, the risks to human health of which were not clear till now. Further study should be conducted for the standard limit of these pathogens in treated wastewater.

Aeromonas hydrophila was very common in raw wastewater, and its numbers were still very high after treatment. There were no significant differences between the frequency of $A$. hydrophila in the phyllosphere, rhizosphere soil and non-rhizosphere soil. There were also no significant differences between treatments irrigated with raw wastewater and treated wastewater, as compared to the control. The quantity of $A$. hydrophila was still up to seven orders of magnitude. A. hydrophila is widely distributed in different aquatic environments in nature; it is an opportunistic pathogen, which could lead to food poisoning, waterborne diseases, infectious diarrhea, secondary infections and sepsis. It is therefore very dangerous to come into contact with $A$. hydrophila directly or by eating vegetables infected with the bacteria.

The number of Arcobacter spp. in wastewater was very high and could reach the same order of magnitude as the total bacteria. Quantities of Arcobacter spp. in the phyllosphere were higher than in soil; similarly, the bacterium was more frequent in plants irrigated with wastewater than in the control, while plants irrigated with treated wastewater were not significantly different from the control. Arcobacter spp. is a foodborne and waterborne pathogen. Of all of the species, A. cryaerophilus, A. butzleri and A. skirrowii are pathogens associated with human gastroenteritis and bacteremia [41,42]. So far, the pathogenesis of Arcobacter spp. is not clear. The possible infection pathways of Arcobacter spp. may include direct contact or eating contaminated food or drinking water.

Human pathogenic bacteria can be colonized both in phyllosphere and rhizosphere, and accordingly, some outbreaks of foodborne illnesses have been reported, which were associated with human consumption [43]. Contamination with E. coli in all treatments followed the order of phyllosphere $>$ rhizosphere $>$ non-rhizosphere. This was quite different from other bacteria mentioned above; E. coli more easily to survived in the phyllosphere, which might be more easily colonized than other pathogens. Some studies have proven the ability of intestinal pathogens, such as E. coli, Salmonella spp. and Bacteroides, to internalize and colonize into plant leaves through wounds, stomata or root uptake and migration $[44,45]$, which could be contaminated via rainwater and irrigation water. E. coli is a foodborne pathogen used as a health standard for drinking water and food. Pathogenic E. coli could cause a disease outbreak through contaminated drinking water, food and aquatic environment, which could potentially be life-threatening.

In summary, there were no significant differences between the control and plants irrigated with treated wastewater, suggesting that treated wastewater can be used as a valid alternative for agricultural reuse. This result is coincident with the report by Jang et al. [46], which concluded that reclaimed wastewater irrigation in rice paddies presents no increased human health or eco-environmental risks. However, the pathogens in both phyllosphere and soils irrigated by raw wastewater showed higher contents than the control. Pathogens in sewage are directed into the soil through irrigation, and soil can provide more suitable conditions (such as temperature, moisture, nutrients, and so on) for the survival of microorganisms. The potential risks of pathogens in the wastewater irrigation process need further assessment. 


\section{Conclusions}

Although rural domestic wastewater irrigation could improve soil fertility and plant yields, pathogens might be transported into soil through irrigation with raw wastewater and then transmitted to the plant in greenhouse conditions. Since vegetables contaminated with pathogenic bacteria are an important pathway of intestinal infectious diseases, more attention should be paid to the potential risks of wastewater irrigation in greenhouses for vegetable planting. The pathogens in the wastewater irrigation process should be further investigated in field conditions.

\section{Acknowledgments}

This work was supported by the Key Project of Chinese Academy of Sciences (Nos. KZZD-EW-09-3 and KZZD-EW-11-3), the National Science and Technology Major Project of China (Nos. 2012ZX07203-006 and 2014ZX07204-005) and the Special Funds of the National Academy Alliance (2012-1).

\section{Author Contributions}

Bo Yang, Xiao Kong, Bingjian Cui, Decai Jin and Zhihui Bai designed and carried out the experiments and analyzed the data. Xiao Kong wrote the main manuscript text. All authors reviewed and improved the manuscript. Zhihui Bai supervised the project.

\section{Conflicts of Interest}

The authors declare no conflict of interest.

\section{References}

1. Jiang, Y. China's water scarcity. J. Environ. Manag. 2009, 90, 3185-3196.

2. Li, L.J.; Li, B.Q. The problems of water resources in north China and the strategy. Chin. Geogr. Sci. 1992, 2, 183-196.

3. Zhang, J.Y.; He, R.M.; Qi, J.; Liu, C.S.; Wang, G.Q.; Jin, J.L. A new perspective on water issues in North China. Adv. Water Sci. 2013, 24, 303-310.

4. Srinivasan, J.T.; Reddy, V.R. Impact of irrigation water quality on human health: A case study in India. Ecol. Econ. 2009, 68, 2800-2807.

5. Sharma, R.K.; Agarwal, M.; Marshall, F. Heavy metal contamination in vegetables grown in wastewater irrigated areas of Varanasi, India. Bull. Environ. Contam. Toxicol. 2006, 77, 312-318.

6. Lado, M.; Bar-Tal, A.; Azenkot, A.; Assouline, S.; Ravina, I.; Erner, Y.; Fine, P.; Dasberg, S.; Ben-Hur, M. Changes in Chemical Properties of Semiarid Soils under Long-Term Secondary Treated Wastewater Irrigation. Soil Sci. Soc. Am. J. 2012, 76, 1358-1369.

7. Toze, S. Reuse of effluent water- benefits and risks. Agric. Water Manag. 2006, 80, 147-159.

8. Al-Sa'ed, R. Pathogens assessment in reclaimed effluent used for industrial crops irrigation. Int. J. Environ. Res. Public Health 2007, 4, 68-75. 
9. Rehman, K.; Ashraf, S.; Rashid, U.; Ibrahim, M.; Hina, S.; Iftikhar, T.; Ramzan, S. Comparison of proximate and heavy metal contents of vegetables grown with fresh and wastewater. Pak. J. Bot. 2013, 45, 391-400.

10. Pereira, L.S.; Oweis, T.; Zairi, A. Irrigation management under water scarcity. Agric. Water Manag. 2002, 57, 175-206.

11. Murtaza, G.; Ghafoor, A.; Qadir, M.; Owens, G.; Aziz, M.A.; Zia, M.H.; Saifullah. Disposal and use of sewage on agricultural lands in Pakistan: A review. Pedosphere 2010, 20, 23-34.

12. Peasey, A.; Blumenthal, U.; Mara, D.; Ruiz-palacios, P.G. A Review of Policy and Standards for Wastewater reuse in Agriculture: A Latin American Perspective. Well Study, Task No. 68 Part II, 2000. Available online: http://www.lboro.ac.uk/well (accessed on 13 January 2014).

13. Elifantz, H.; Kautsky, L.; Mor-Yosef, M.; Tarchitzky, J.; Bar-Tal, A.; Chen, Y.N.; Minz, D. Microbial activity and organic matter dynamics during 4 years of irrigation with treated wastewater. Microb. Ecol. 2011, 62, 973-981.

14. Meli, S.; Porto, M.; Belligno, A.; Bufo, S.A.; Mazzatura, A.; Scopa, A. Influence of irrigation with lagooned urban wastewater on chemical and microbiological soil parameters in a citrus orchard under Mediterranean condition. Sci. Total. Environ. 2002, 285, 69-77.

15. Speir, T.W. Soil biochemical properties as indices of performance and sustainability of effluent irrigation systems in New Zealand-A review. J. Roy. Soc. N. Z. 2002, 32, 535-553.

16. Lv, M.C.; Cai, H.J.; Chen, X.M. Effects of sewage irrigation on physiological characteristics of potato and soil environment. J. Irrig. Drain. 2007, 26, 26-29.

17. Al-Lahham, O.; el Assi, N.M.; Fayyad, M. Impact of treated wastewater irrigation on quality attributes and contamination of tomato fruit. Agric. Water Manag. 2003, 61, 51-62.

18. Singh, P.K.; Deshbhratar, P.B.; Ramteke, D.S. Effect of sewage wastewater irrigation on soil properties, crop yield and environment. Agric. Water Manag. 2012, 103, 100-104.

19. Maldonado, V.M.; Rubio Arias, H.O.; Quintana, R.; Saucedo, R.A.; Gutierrez, M.; Ortega, J.A.; Nevarez, G.V. Heavy Metal Content in Soils under Different Wastewater Irrigation Patterns in Chihuahua, Mexico. Int. J. Environ. Res. Public Health 2008, 5, 441-449.

20. Tsado, E.K.; Adesina, O.A.; Oyeleke, S.B. A Survey on the Bacterial Load of Selected Fruits and Leafy Vegetables in Minna Metropolis of Niger State. Niger. J. Anim. Prod. Adv. 2013, 3, 6-11.

21. Ministry of Health of P.R. China; Standardization Administration of P.R. China. Standards for Drinking Water Quality; GB 5749-2006; The National Standard of the People's Republic of China; Ministry of Health of P.R.: Beijing, China, 2006.

22. Ministry of Environmental Protection of P.R. China. Standards for Irrigation Water Quality; GB 5084-92; The National Standard of the People's Republic of China; Ministry of Environmental Protection of P.R. China: Beijing, China, 1992;.

23. Morugán-Coronado, A.; García-Orenes, F.; Mataix-Solera, J.; Arcenegui, V.; Mataix-Beneyto, J. Short-term effects of treated waste water irrigation on Mediterranean calcareous soil. Soil Tillage Res. 2011, 112, 18-26.

24. Tabatabai, M.A. Chemical and microbiological properties. In Methods of Soil Analysis; Soil Science Society of America: Madison, WI, USA, 1982; pp. 903-947.

25. Cataldo, D.A.; Haroon, M.; Schrader, L.E.; Young, V.L. Rapid colorimetric determination of nitrate in plant tissues by nitration of salicylic acid. Commun. Soil Sci. Plant Anal. 1975, 6, 71-80. 
26. Dubois, M.; Gilles, K.A.; Hamilton, J.K.; Rebers, P.A.; Smith, F. Colorimetric method for determination of sugars and related substances. Anal. Chem. 1956, 28, 350-356.

27. Lowry, O.H.; Rosebrough, N.J.; Farr, A.L.; Randall, R.J. Protein measurement with the folin phenol reagent. J. Biol. Chem. 1951, 193, 265-275.

28. Tee, E.S.; Young, S.; Young, S.I.; Ho, S.K.; Mizura, S.S. Determination of vitamin C in fresh fruits and vegetables using the dye-titration and microfluorometric methods. Pertanika 1988, 11, 39-44.

29. Kingombe, C.I.; Huys, G.; Tonolla, M.; Albert, M.J.; Swings, J.; Peduzzi, R.; Jemmi, T. PCR detection, characterization, and distribution of virulence genes in Aeromonas spp. Appl. Environ. Microbiol. 1999, 65, 5293-5302.

30. Bastyns, K.; Cartuyvels, D.; Chapelle, S.; Vandamme, P.; Goossens, H.; DeWachter, R. A variable $23 \mathrm{~S}$ rDNA region is a useful discriminating target for genus-specific and species-specific PCR amplification in Arcobacter species. Syst. Appl. Microbiol. 1995, 18, 353-356.

31. Priha, O.; Hallamaa, K.; Saarela, M.; Raaska, L. Detection of Bacillus cereus group bacteria from cardboard and paper with real-time PCR. J. Ind. Microbiol. Biot. 2004, 31, 161-169.

32. Rinttila, T.; Kassinen, A.; Malinen, E.; Krogius, L.; Palva, A. Development of an extensive set of 16S rDNA-targeted primers for quantification of pathogenic and indigenous bacteria in faecal samples by real-time PCR. J. Appl. Microbiol. 2004, 97, 1166-1177.

33. Kaushik, R.; Balasubramanian, R.; de la Cruz, A.A. Influence of air quality on the composition of microbial pathogens in fresh rainwater. Appl. Environ. Microbiol. 2012, 78, 2813-2818.

34. Miyamoto, H.; Yamamoto, H.; Arima, K.; Fujii, J.; Maruta, K.; Izu, K.; Shiomori, T.; Yoshida, S. Development of a new seminested PCR method for detection of Legionella species and its application to surveillance of legionellae in hospital cooling tower water. Appl. Environ. Microbiol. 1997, 63, 2489-2494.

35. Mendum, T.A.; Chilima, B.Z.; Hirsch, P.R. The PCR amplification of non-tuberculous mycobacterial 16S rRNA Sequences from soil. FEMS Microbiol. Lett. 2000, 185, 189-192.

36. Basic Local Alignment Search Tool. Available online: http://blast.ncbi.nlm.nih.gov/Blast.cgi (accessed on 7 December 2013).

37. Whelan, J.A.; Russell, N.B.; Whelan, M.A. A Method for the absolute quantification of cDNA using real-time PCR. J. Immunol. Methods 2003, 278, 261-269.

38. Ministry of Environmental Protection of P.R. China. Environmental Quality Evaluation Standards for Farmland of Edible Agricultural Products; The National Standard of the People's Republic of China; Ministry of Environmental Protection of P.R. China: Beijing, China, 2006.

39. Song, C.-Y.; Zhang, X.-Y.; Liu, X.-B.; Gao, C.-S. Effect of soil organic matter on soil fertility and crop productivity. Syst. Sci. Comp. Stud. Agric. 2008, 24, 357-362.

40. Brady, N.C.; Weil, R.R. The Nature and Properties of Soil, 13th ed.; Prentice Hall: Upper Saddle River, NJ, USA, 2002.

41. Ho, H.T.K.; Lipman, L.J.A.; Gaastra, W. Arcobacter, what is known and unknown about a potential foodborne zoonotic agent. Vet. Microbiol. 2006, 115, 1-13.

42. Bi, S.L.; Meng, H.C. Biological characteristics and diagnoses of pathogenic Arcobacter species. Mod. Food Sci. Technol. 2013, 29, 211-214. 
43. Quilliam, R.S.; Williams, A.P.; Jones, D.L. Lettuce cultivar mediates both phyllosphere and rhizosphere activity of Escherichia coli O157:H7. PLoS ONE 2012, 7, doi:10.1371/journal.pone.0033842.

44. Kroupitski, Y.; Golberg, D.; Belausov, E.; Pinto, R.; Swartzberg, D.; Granot, D.; Sela, S. Internalization of Salmonella enterica in leaves is induced by light and involves chemotaxis and penetration through open stomata. Appl. Environ. Microbial. 2009, 75, 6076-6086.

45. Solomon, E.B.; Yaron, S.; Matthews, K.R. Transmission of Escherichia coli O157:H7 from contaminated manure and irrigation water to lettuce plant tissue and its subsequent internalization. Appl. Environ. Microbiol. 2002, 68, 397-400.

46. Jang, T.; Jung, M.; Lee, E. Assessing environmental impacts of reclaimed wastewater irrigation in paddy fields using bioindicator. Irrig. Sci. 2013, 31, 1225-1236.

(C) 2015 by the authors; licensee MDPI, Basel, Switzerland. This article is an open access article distributed under the terms and conditions of the Creative Commons Attribution license (http://creativecommons.org/licenses/by/4.0/). 